What are the barriers and enablers to physical activity participation in women with ovarian cancer? A rapid review of the literature.

MORRISON, K.S., PATERSON, C., COLTMAN, C.E. and TOOHEY, K. 


\section{What are the barriers and enablers to physical activity participation in women with ovarian cancer? A rapid review of the literature}

Kittani S. Morrison (BExPhysRehab, AEP) ${ }^{\mathrm{a}^{*}}$, Catherine Paterson (PhD, BA, MSc, PgCert LTA, FHAE) $)^{\mathrm{a}, \mathrm{b}, \mathrm{d}, \mathrm{e}}$, Celeste E. Coltman (PhD, BSc (Hons)) $)^{\mathrm{a}, \mathrm{c}}$, Kellie Toohey (PhD, MCEP, BSc, PG Cert Research, PG Cert Tertiary Ed, AEP) $)^{\mathrm{a}, \mathrm{b}}$

${ }^{a}$ Faculty of Health, University of Canberra, Bruce ACT, Australia

${ }^{b}$ Prehabilitation, Activity, Cancer, Exercise and Survivorship (PACES) Research Group,

University of Canberra, Bruce ACT, Australia

${ }^{c}$ University of Canberra Research Institute for Sport and Exercise, University of Canberra,

Bruce ACT, Australia

${ }^{d}$ School of Nursing, Midwifery and Public Health, University of Canberra, Bruce ACT, Australia

${ }^{e}$ Canberra Health Services \& ACT Health, SYNERGY Nursing \& Midwifery Research Centre, ACT Health Directorate Level 3, Building 6, Canberra Hospital, Australia

*Corresponding Author at: Faculty of Health, University of Canberra, ICON Building (Canberra Specialist Medical Centre), Level C Office 3, 11 Kirinari Street, Bruce ACT 2617. E-mail address: kittani.morrison@canberra.edu.au (K. Morrison).

Declarations of interest: Dr's Toohey and Paterson are Morrison's academic supervisors and editors of this issue. This is an original research contribution relevant to this special issue on exercise in cancer care.

June 2020 


\section{ABSTRACT}

Background: Engagement in regular physical activity is recommended for women diagnosed with ovarian cancer due to aggressive treatment approaches, an increased risk of disease recurrence and low survival rates.

Objectives: To synthesise the current available evidence identifying barriers and enablers to participation in physical activity among women diagnosed with ovarian cancer.

Data Sources: Peer reviewed articles in electronic databases including CINAHL, Cochrane, Medline, Psych INFO and Scopus and key studies' reference lists.

Conclusions: Although evidence pertaining to the study population was limited, the findings of this review suggest women with ovarian cancer experience similar barriers and enablers to the general population and other cancer cohorts. The primary barriers to physical activity participation reported by this population were treatment or disease related side effects, fear of injury or falling and the absence of physical activity counselling. Key enablers reported to facilitate physical activity participation were the implementation of individualised interventions with targeted goals in addition to support from health and medical professionals. Future research on ovarian cancer populations is warranted to confirm this notion.

Implications for Nursing Practice: Nurses working within the oncology field are well positioned clinically to facilitate physical activity engagement and identify and overcome barriers to participation within a population that experiences high mortality rates and disease recurrence.

Key words: Ovarian cancer, physical activity, exercise, barriers, facilitators, rapid review. 


\section{INTRODUCTION}

Ovarian cancer has a relative five-year survival rate of $45.7 \%$ and in 2019 had the highest mortality rate of any cancer of the female reproductive system. ${ }^{1}$ There is no early effective screening test available to diagnose ovarian cancer, and most women initially present with vague, non-specific symptoms. ${ }^{2}$ Consequently, a clinical diagnosis usually occurs at an advanced stage of disease. An advanced diagnosis of ovarian cancer is associated with a poor prognosis and high risk of recurrent disease. $^{3}$ Initial treatment commonly involves a combination of platinum-based chemotherapy and surgery, and recurrent disease often requires additional cytoreductive surgery involving resection of the bowel or other organs. ${ }^{4}$ Women often remain or become sedentary after diagnosis, ${ }^{5}$ with evidence acknowledging that a lack of physical activity can further impair physical function and quality of life ${ }^{6}$; concurrently increasing levels of anxiety and depression. ${ }^{2}$

Physical activity is an intervention that has been suggested to combat adverse side effects of cancer treatment and improve quality of life. ${ }^{2}$ Physical activity is defined as any movement of the body produced by skeletal muscle contractions, and includes every day activities such as house work, grocery shopping or gardening. ${ }^{7}$ Exercise is a sub-category of physical activity, and refers to structured, intentional or planned movement with the intention of improving/maintaining physical fitness. ${ }^{7}$ Physical activity will be the primary focus of this rapid review; however, it is important to recognise that published literature uses both terms (physical activity and exercise) interchangeably., ${ }^{7,8}$ The positive effects of physical activity for individuals diagnosed with any type of cancer has been outlined in existing literature. ${ }^{9,10}$

Physical activity also plays a key role in the prevention of other chronic diseases and the management of treatment related side effects. ${ }^{10}$ As a result of the positive association between physical activity and health outcomes, the Clinical Oncology Society of Australia released a position statement in 2019 , calling for physical activity to be included in standard 
cancer care. ${ }^{11}$ Similarly, in 2019, Exercise and Sports Science Australia also released evidencebased guidelines to support the implementation of physical activity interventions throughout the cancer continuum. ${ }^{12}$ These recent statements demonstrate the growing body of evidence to underscore the importance of physical activity programmes to be included in standard cancer care services. Importantly, research has identified that it is safe and feasible for women diagnosed with ovarian cancer to participate in physical activity, irrespective of their stage of disease or treatment modality. ${ }^{13,14}$

Despite the known benefits of physical activity for individuals diagnosed with cancer ${ }^{9}$, research $^{15}$ from one study reported that the majority $(81 \%, \mathrm{~N}=95)$ of participants (women living with ovarian cancer) do not adhere to the American College of Sports Medicine physical activity guidelines. ${ }^{16}$ These guidelines accommodate chronic conditions and recommend individuals diagnosed with cancer engage in a weekly minimum of 150 minutes of moderate intensity aerobic activity and two-three strength training sessions. ${ }^{16}$ The reasons for nonadherence to physical activity recommendations within ovarian cancer survivors are largely unknown but are hypothesised to be linked with aggressive treatment strategies such as major abdominal surgery and the high rates of disease recurrence. ${ }^{2,15}$

To date, there has been only one published study ${ }^{15}$ that has exclusively explored the barriers to physical activity participation in a sample of women with ovarian cancer $(\mathrm{N}=95)$. Utilising a questionnaire, researchers found fatigue, lack of routine and lack of self-discipline were the most commonly reported barriers among participants. ${ }^{15}$ The researchers from this study highlighted the limitation of collecting data via a questionnaire as this tool did not capture unique barriers specific to ovarian cancer. ${ }^{15}$ Beyond this study, several other studies ${ }^{17-20}$ have investigated barriers to physical activity in samples of mixed gender and cancer types, which also included women with ovarian cancer. These studies found that the primary barriers to physical activity were individual disease related factors (primarily fatigue) and availability of 
cancer specific facilities and programs. ${ }^{17-19}$ Although these studies provide some evidence of the barriers to physical activity that may be experienced by people with cancer, it is important to acknowledge that the findings from these studies cannot be generalised to women with ovarian cancer due to the heterogeneity of the study samples and the aggregation of the reported findings across these studies. ${ }^{15-17}$

In contrast to barriers, enablers of physical activity are behaviours that facilitate participation in physical activity and provide solutions to overcome barriers. ${ }^{21}$ Despite their importance to the promotion of physical activity, limited literature has investigated enablers to physical activity in women with ovarian cancer. Understanding physical activity enablers is vital in this population given the limited research that indicates women with ovarian cancer are inactive. ${ }^{15}$ One study investigating enablers in ovarian cancer survivors $(\mathrm{N}=395)$ reported $49 \%$ of participants preferred home based programs, with $63 \%$ reporting walking as their preferred activity mode. ${ }^{22}$ Preferences were captured via a questionnaire, which limits the depth of information captured and lacks exploration into personal attribute factors, emphasising the need for further research exploring physical activity enablers. The aim of this rapid review is to synthesise current available evidence to identify reasons why women with ovarian cancer are not physically active and investigate factors that facilitate participation in physical activity. This rapid review is driven by the following research question, "What are the barriers and enablers to participation in physical activity in women with ovarian cancer?" It is anticipated that the results of this rapid review will inform future research directions, as well as clinical practice. 


\section{METHODS}

\section{Search strategy}

The systematic literature search was conducted via a computer search of five databases (CINAHL, Cochrane, Medline, Psych INFO and Scopus) for appropriate papers from 1988 until February 2020. Electronic searches began on the $1^{\text {st }}$ February 2020 and concluded on $29^{\text {th }}$ February 2020. Search terms were developed with the assistance of a professional librarian and review of the existing literature. Medical subject headings (MeSH) for 'ovarian neoplasms' and 'exercise' were used. Search terms included were (ovarian neoplasms OR ovarian cancer) AND (exercise OR exercise therapy OR physical activity OR exercise intervention OR therapeutic exercise) AND (barriers OR challenges OR difficulties OR issues) AND (enablers OR facilitators OR motivators). These search terms were combined using 'AND' and searched in 'All Fields' of each database. Reference lists of full text articles were reviewed to ensure no studies were overlooked.

\section{Inclusion and exclusion criteria}

Peer-reviewed papers published between 1988 and February 2020 were included in this search. Qualitative and quantitative research was included, irrespective of research design. Due to the limited research specific to only women with ovarian cancer, studies with a mixed sample of cancer types (including ovarian cancer) were accepted, even if they did not report results of each cancer type separately of one another. Given this is a topic with a developing evidence base, this decision was made to be inclusive of all women with ovarian cancer who have partaken in research. To ensure all relevant literature was captured, studies that investigated women with ovarian cancer were included irrespective of the cancer stage, treatment type or primary/secondary nature of disease. Articles were included if they investigated or inadvertently explored barriers and/or enablers to engagement in physical activity and/or exercise. Barriers to physical activity are any patient-reported reasons for not engaging in 
physical activity. ${ }^{21}$ Enablers are described as any reasons or preferences which motivate or facilitate an individual to engage in physical activity. ${ }^{21}$ Articles were excluded if they did not identify data linked to the primary research question. Case reports/case studies, narrative reviews, commentaries, conference abstracts and editorials were excluded. Articles that were in a language other than English, involved animals or in vitro experiments were also excluded.

\section{Data management and selection procedure}

Articles were initially imported into a web-based data management platform (Covidence ${ }^{\odot}$ 2020, Version 1517, Melbourne, Australia) for screening. All duplicated were removed. All titles were initially screened by KM using the inclusion and exclusion criteria. Abstracts and titles were screened by two reviewers (KM and KT), with any conflicts resolved by a third reviewer $(\mathrm{CP})$. All full texts were screened by one reviewer $(\mathrm{KM})$, where studies were excluded based on the pre-determined exclusion criteria. This review followed a rapid review methodology, ${ }^{23}$ which was modified to accommodate a limited timeframe to progress the future proposed qualitative study in women affected by ovarian cancer. This rapid review did not have a second reviewer during the full text screening, data extraction, and quality appraisal stages.

\section{Quality appraisal}

Study quality was assessed using the Mixed Methods Appraisal Tool (2018 Version). ${ }^{24}$ The Mixed Methods Appraisal Tool includes specific criteria for qualitative, quantitative and mixed methods studies, focusing on methodological quality. ${ }^{24}$ Each study included in the quality appraisal was evaluated by one reviewer (KM). Every study was assigned a score (0-2) based on each question within the appraisal tool; with a rating of 2 adopted to indicate a low risk of 
bias, a rating of 1 indicating an unclear risk of bias and a rating of 0 indicating a high risk of bias. No studies were excluded based on the quality appraisal.

\section{Data extraction}

Data extraction was completed by one reviewer $(\mathrm{KM})$ in a Microsoft ${ }^{\circ}$ Excel spreadsheet. Initial data extraction included information on study design, aim, setting, location, sample size, sample characteristics, outcome measures, key findings and future directions. Data extraction was consistent irrespective of design. Further data extraction captured reported barriers and enablers to physical activity participation.

\section{Data synthesis}

Given the heterogeneity of the study samples and designs, a narrative synthesis and tabulation approach was adopted. ${ }^{25}$ The narrative synthesis followed the steps of data reduction, data comparison and conclusion drawing. Data reduction involved the identification of primary themes (barriers and enablers), which were then divided into subgroups to facilitate clearer analysis. This subgroup classification was based on conceptual classification of participants experiences and attitudes, discussed and agreed upon by the entire research team. Individual barriers and enablers under each subgroup were then examined for prevalence using frequency counts in Microsoft $^{\odot}$ Excel. Data comparison involved identifying patterns, themes or relationships between data and grouping similar themes together. ${ }^{25}$ Conclusions were drawn by verifying themes and subgroups against the primary data source. 


\section{RESULTS}

\section{Search results and overview}

The flow of records through the rapid review is summarised in Figure 1. The initial search yielded 96 articles after the removal of duplicates. Based on the screening of titles and abstracts, a further 56 articles were excluded. No additional studies were identified from the reference lists. Twenty studies were read in full and eleven publications were excluded due to being inaccessible or not meeting the primary research objective. Subsequently, two mixed methods, six quantitative studies and one qualitative study published between 2009 and 2020 were included in the final rapid review. A total of 1479 participants (of which 264 were diagnosed with ovarian cancer) were included across the studies and sample sizes ranged from $\mathrm{N}=10$ to $\mathrm{N}=456$ (age range: $50-66$ years). An overview of the included studies, including participant characteristics can be found in Table 1. Two articles included only participants with ovarian cancer, with the remaining seven articles containing mixed and female gynaecological cancer cohorts with a subset of ovarian cancer participants comprising each studies sample. Data was extracted from all articles, irrespective of sub-analysis for cancer type. 


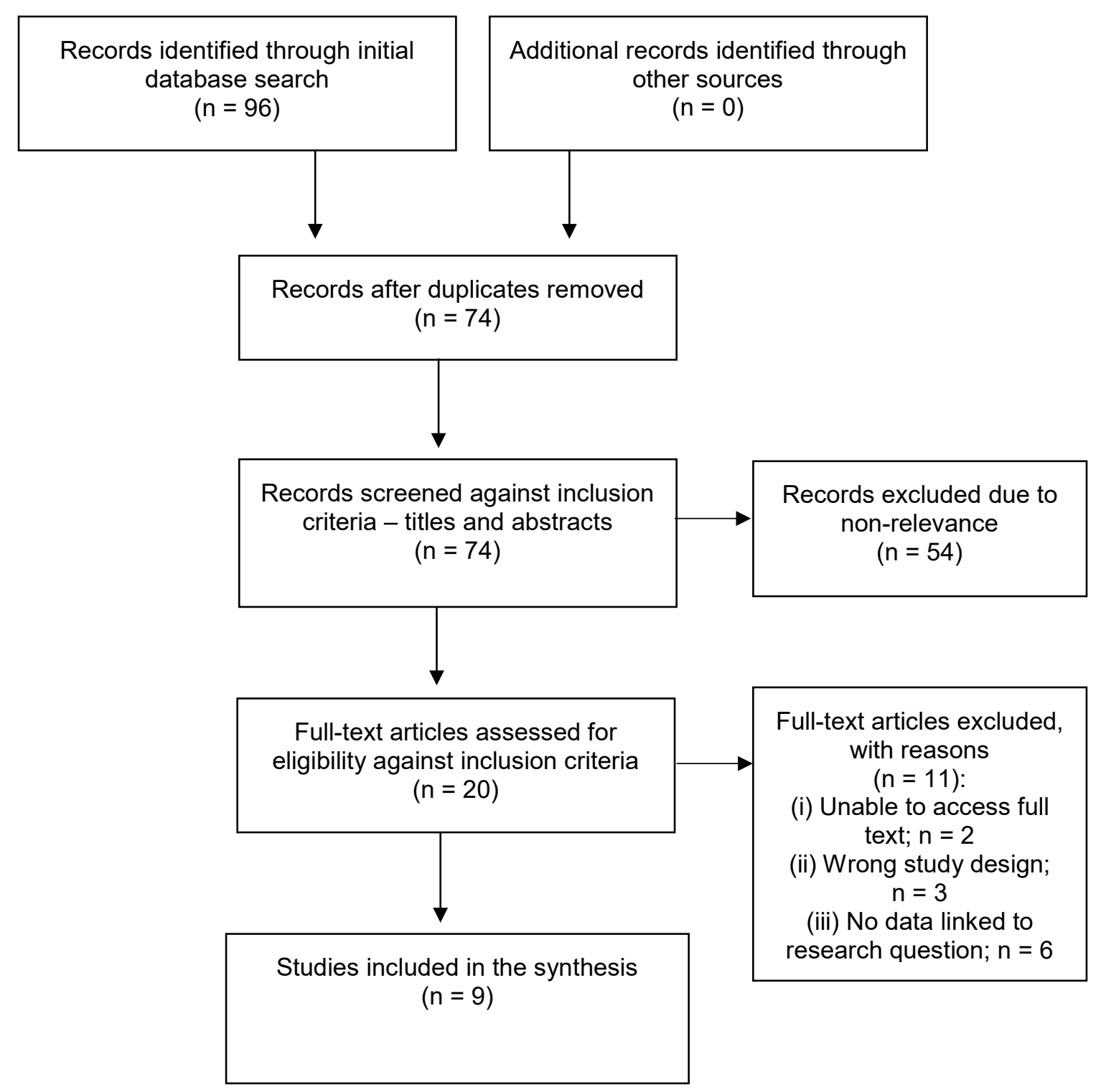

Figure 1. PRISMA flow diagram of the study selection, including literature search and reasons for exclusion. 
Table 1. Overview of the included studies $(\mathrm{N}=9)$.

\begin{tabular}{|c|c|c|c|c|c|c|c|c|c|c|}
\hline $\begin{array}{l}\text { Author } \\
\text { and Year }\end{array}$ & Purpose & Setting & Country & Sample Size & $\begin{array}{l}\text { Mean } \\
\text { Age } \\
\text { (years } \\
\text { ) }^{*}\end{array}$ & Treatment Type & $\begin{array}{l}\text { Study } \\
\text { Design }\end{array}$ & $\begin{array}{l}\text { Outcome } \\
\text { Measures }\end{array}$ & Key Findings & Future Directions \\
\hline $\begin{array}{l}\text { Beck et al., } \\
2020\end{array}$ & $\begin{array}{l}\text { To investigate if } \\
\text { prehabilitation } \\
\text { recommendations were } \\
\text { more likely to be adhered } \\
\text { to with the use of an } \\
\text { educational support } \\
\text { pamphlet. }\end{array}$ & $\begin{array}{l}\text { University } \\
\text { Hospitals }\end{array}$ & Denmark & $\begin{array}{l}\text { Overall } \\
\text { sample } \\
\mathrm{N}=53 \\
\text { (Ovarian } \\
\text { cancer } \\
\mathrm{N}=33 \text { ) }\end{array}$ & 66.0 & Not reported. & $\begin{array}{l}\text { Mixed } \\
\text { methods }\end{array}$ & $\begin{array}{l}\text { Leaflet; face- } \\
\text { to-face } \\
\text { interviews }\end{array}$ & $\begin{array}{l}\text { Prehabilitation } \\
\text { recommendations were too } \\
\text { generalised and could } \\
\text { represent a barrier to } \\
\text { adherence; more tailored } \\
\text { interventions needed to } \\
\text { promote adherence. }\end{array}$ & $\begin{array}{l}\text { To combine patient preference with } \\
\text { biomedical evidence to optimise } \\
\text { prehabilitation programs. }\end{array}$ \\
\hline $\begin{array}{l}\text { Blaney et } \\
\text { al., } 2013\end{array}$ & $\begin{array}{l}\text { To investigate exercise } \\
\text { barriers, facilitators and } \\
\text { preferences. }\end{array}$ & $\begin{array}{l}\text { Cancer } \\
\text { Care } \\
\text { Charity }\end{array}$ & Ireland & $\begin{array}{l}\text { Overall } \\
\text { sample } \\
\mathrm{N}=456 \\
(\text { Ovarian } \\
\text { cancer } \mathrm{N}=4)\end{array}$ & 61.0 & $\begin{array}{l}\text { Surgery }(14.4 \%) \\
\text { Chemotherapy } \\
\text { alone }(6.9 \%) ; \\
\text { Radiotherapy } \\
\text { alone }(6.6 \%) ; \\
\text { Chemotherapy + } \\
\text { radiotherapy } \\
(2.9 \%) ; \\
\text { Surgery and } \\
\text { chemotherapy } \\
+/- \text { radiotherapy } \\
(67.7 \%)\end{array}$ & $\begin{array}{l}\text { Descriptive } \\
\text { cross- } \\
\text { sectional } \\
\text { study }\end{array}$ & $\begin{array}{l}\text { Questionnaire; } \\
\text { MSFI-FS; } \\
\text { EORTC QLQ- } \\
\text { C30; LSI. }\end{array}$ & $\begin{array}{l}\text { Exercise facilitators, } \\
\text { preferences and motivators } \\
\text { are related to cancer } \\
\text { survivor's needs. } \\
\text { Primary barriers discovered } \\
\text { were health related or } \\
\text { linked to facility access. }\end{array}$ & $\begin{array}{l}\text { To include a wide variety of cancer } \\
\text { diagnosis in future questionnaires. } \\
\text { Future questionnaires investigating } \\
\text { physical activity should include } \\
\text { intensity, duration and frequency. }\end{array}$ \\
\hline $\begin{array}{l}\text { Farrokhza } \\
\text { di et al., } \\
2016\end{array}$ & $\begin{array}{l}\text { To identify physical } \\
\text { activity barriers and } \\
\text { preferences in women } \\
\text { with gynaecological } \\
\text { cancers. }\end{array}$ & Hospitals & Australia & $\begin{array}{l}\text { Overall } \\
\text { sample } \\
\mathrm{N}=101 \\
\text { (Ovarian } \\
\text { cancer } \\
\mathrm{N}=59 \text { ) }\end{array}$ & 57.5 & $\begin{array}{l}\text { Chemotherapy } \\
\text { or radiation } \\
\text { therapy }(60 \%)\end{array}$ & $\begin{array}{l}\text { Descriptive } \\
\text { cross- } \\
\text { sectional } \\
\text { survey }\end{array}$ & $\begin{array}{l}\text { Questionnaire; } \\
\text { Active } \\
\text { Australia } \\
\text { Survey; SF-36; } \\
\text { Godin-Leisure } \\
\text { Time. }\end{array}$ & $\begin{array}{l}\text { Barriers such as fatigue } \\
\text { and poor health were } \\
\text { linked with low levels of } \\
\text { physical activity. Odds of } \\
\text { having disease specific } \\
\text { barriers were highest for } \\
\text { women with ovarian cancer } \\
(p=0.04) \text {. }\end{array}$ & $\begin{array}{l}\text { Interventions to increase physical } \\
\text { activity should address disease } \\
\text { specific barriers. }\end{array}$ \\
\hline $\begin{array}{l}\text { Lapen et } \\
\text { al., } 2018\end{array}$ & $\begin{array}{l}\text { To determine the } \\
\text { feasibility of two different } \\
\text { types of yoga } \\
\text { intervention for sedentary } \\
\text { cancer survivors. }\end{array}$ & $\begin{array}{l}\text { Cancer } \\
\text { Centre }\end{array}$ & $\begin{array}{l}\text { United } \\
\text { States of } \\
\text { America }\end{array}$ & $\begin{array}{l}\text { Overall } \\
\text { sample } \\
\mathrm{N}=42 \\
\text { (Ovarian } \\
\text { cancer } \mathrm{N}=2 \text { ) }\end{array}$ & 56.5 & Not reported. & $\begin{array}{l}\text { Pilot } \\
\text { randomise } \\
\text { d study }\end{array}$ & $\begin{array}{l}\text { Accrual, } \\
\text { adherence and } \\
\text { attendance } \\
\text { rates. }\end{array}$ & $\begin{array}{l}\text { Ovarian cancer survivors } \\
\text { can participate in a } \\
\text { restorative yoga } \\
\text { intervention; however, time } \\
\text { commitment and travel } \\
\text { distance were cited } \\
\text { barriers. }\end{array}$ & $\begin{array}{l}\text { Address barriers such as time } \\
\text { commitment and travel } \\
\text { requirements to improve } \\
\text { recruitment. } \\
\text { Investigate restorative yoga as a } \\
\text { more feasible intervention in cancer } \\
\text { survivors. }\end{array}$ \\
\hline
\end{tabular}




\begin{tabular}{|c|c|c|c|c|c|c|c|c|c|c|}
\hline $\begin{array}{l}\text { Midtgaard } \\
\text { et al., } 2009\end{array}$ & $\begin{array}{l}\text { To investigate self- } \\
\text { reported physical activity } \\
\text { behaviour and exercise } \\
\text { motivation in cancer } \\
\text { patients undergoing } \\
\text { chemotherapy. }\end{array}$ & $\begin{array}{l}\text { University } \\
\text { Hospital }\end{array}$ & Denmark & $\begin{array}{l}\text { Overall } \\
\text { sample } \\
\mathrm{N}=451 \\
\text { (Gynaecolog } \\
\text { ical cancer } \\
\mathrm{N}=114 \text { ) }\end{array}$ & 50.2 & $\begin{array}{l}\text { Chemotherapy } \\
\text { and/or radiation } \\
\text { therapy (\% not } \\
\text { reported). }\end{array}$ & $\begin{array}{l}\text { Descriptive } \\
\text { cross- } \\
\text { sectional } \\
\text { survey }\end{array}$ & Questionnaire. & $\begin{array}{l}\text { Physical activity levels } \\
\text { declined as treatment } \\
\text { progressed. Primary } \\
\text { exercise barriers were } \\
\text { fatigue and physical } \\
\text { discomfort. Patients } \\
\text { exhibited a positive interest } \\
\text { in physical activity. }\end{array}$ & $\begin{array}{l}\text { To investigate physical activity } \\
\text { intervention to overcome disease } \\
\text { and treatment related side effects. }\end{array}$ \\
\hline $\begin{array}{l}\text { Midtgaard } \\
\text { et al., } 2012\end{array}$ & $\begin{array}{l}\text { To describe cancer } \\
\text { survivor's lived } \\
\text { experience of } \\
\text { postintervention } \\
\text { maintenance of physical } \\
\text { activity. }\end{array}$ & $\begin{array}{l}\text { University } \\
\text { Hospital }\end{array}$ & Denmark & $\begin{array}{l}\text { Overall } \\
\text { sample } \\
\mathrm{N}=23 \\
\text { (Ovarian } \\
\text { cancer } \mathrm{N}=3 \text { ) }\end{array}$ & 50.0 & Not reported. & Qualitative & $\begin{array}{l}\text { Semi- } \\
\text { structured } \\
\text { focus groups. }\end{array}$ & $\begin{array}{l}\text { Cancer survivors } \\
\text { motivation to maintain } \\
\text { physical activity was linked } \\
\text { to living a meaningful live } \\
\text { and fear of what may occur } \\
\text { if they ceased activity. }\end{array}$ & $\begin{array}{l}\text { Develop theory-based interventions } \\
\text { to promote physical activity } \\
\text { maintenance. }\end{array}$ \\
\hline $\begin{array}{l}\text { Mizrahi et } \\
\text { al., } 2015\end{array}$ & $\begin{array}{l}\text { To quantify physical } \\
\text { activity levels in women } \\
\text { with ovarian cancer and } \\
\text { investigate barriers to } \\
\text { physical activity. }\end{array}$ & $\begin{array}{l}\text { Oncology } \\
\text { Clinics }\end{array}$ & Australia & $\begin{array}{l}\text { Overall } \\
\text { sample } \\
\mathrm{N}=95 \\
\text { (Ovarian } \\
\text { cancer } \\
\mathrm{N}=95 \text { ) }\end{array}$ & 58.6 & $\begin{array}{l}\text { Chemotherapy } \\
(39 \%) ; \\
\text { Not on treatment } \\
(61 \%)\end{array}$ & $\begin{array}{l}\text { Descriptive } \\
\text { cross- } \\
\text { sectional } \\
\text { survey }\end{array}$ & $\begin{array}{l}\text { Questionnaire; } \\
\text { IPAQ-SF; } \\
\text { PPABS. }\end{array}$ & $\begin{array}{l}\text { Women with ovarian } \\
\text { cancer are at high risk for } \\
\text { low levels of physical } \\
\text { activity. Majority of barriers } \\
\text { identified were } \\
\text { motivational, environmental } \\
\text { and behaviour-related. }\end{array}$ & $\begin{array}{l}\text { Patient interviews or focus groups } \\
\text { may offer more insight into barriers } \\
\text { to physical activity not captured in } \\
\text { existing questionnaires. } \\
\text { Address motivational, symptomatic } \\
\text { and behavioural barriers. }\end{array}$ \\
\hline $\begin{array}{l}\text { Tyrrell et } \\
\text { al., } 2014\end{array}$ & $\begin{array}{l}\text { To identify and explore } \\
\text { physical activity } \\
\text { preferences of } \\
\text { gynaecologic cancer } \\
\text { survivors. }\end{array}$ & $\begin{array}{l}\text { Cancer } \\
\text { Registry }\end{array}$ & Canada & $\begin{array}{l}\text { Overall } \\
\text { sample } \\
\mathrm{N}=239 \\
\text { (Ovarian } \\
\text { cancer } \\
\mathrm{N}=58 \text { ) }\end{array}$ & 52.9 & Not reported. & $\begin{array}{l}\text { Mixed } \\
\text { methods }\end{array}$ & $\begin{array}{l}\text { Questionnaire; } \\
\text { LSI; IPAQ-SF; } \\
\text { semi- } \\
\text { structured } \\
\text { interviews. }\end{array}$ & $\begin{array}{l}\text { Physical activity support } \\
\text { and counselling was highly } \\
\text { desired among } \\
\text { gynaecologic cancer } \\
\text { survivors. }\end{array}$ & $\begin{array}{l}\text { Investigate specific subgroups to } \\
\text { determine more specific physical } \\
\text { activity preferences in different age } \\
\text { groups and disease stages. }\end{array}$ \\
\hline $\begin{array}{l}\text { Zhang et } \\
\text { al., } 2017\end{array}$ & $\begin{array}{l}\text { To explore the feasibility } \\
\text { for women with ovarian } \\
\text { cancer to complete a } \\
\text { higher dose of planned } \\
\text { physical activity whilst } \\
\text { undergoing active } \\
\text { treatment. }\end{array}$ & University & $\begin{array}{l}\text { United } \\
\text { States of } \\
\text { America }\end{array}$ & $\begin{array}{l}\text { Overall } \\
\text { sample } \\
\mathrm{N}=10 \\
\text { (Ovarian } \\
\text { cancer } \\
\mathrm{N}=10 \text { ) }\end{array}$ & 63.0 & $\begin{array}{l}\text { Chemotherapy } \\
(50 \%) ; \\
\text { Not on treatment } \\
(50 \%)\end{array}$ & $\begin{array}{l}\text { Non- } \\
\text { randomise } \\
\text { d study }\end{array}$ & $\begin{array}{l}\text { Self-report } \\
\text { diary; phone } \\
\text { interviews; } \\
\text { Fitbit Zip. }\end{array}$ & $\begin{array}{l}\text { Data indicates it may be } \\
\text { feasible for women with } \\
\text { ovarian cancer to complete } \\
225 \text { minutes per week of } \\
\text { physical activity with } \\
\text { support of exercise } \\
\text { counselling. }\end{array}$ & $\begin{array}{l}\text { Larger scale, dose-response trial to } \\
\text { investigate therapeutic effects of } \\
\text { exercise intervention ( } 180 \text { and } 225 \\
\text { minutes/week) vs control (no } \\
\text { exercise). }\end{array}$ \\
\hline
\end{tabular}

MSFI-FS: Multidimensional Fatigue Symptom Index - Short Form. EORTC QLQ-C30: European Organisation for Research and Treatment of Cancer Quality of Life Questionnaire - C30. LSI: Leisure Score Index. SF-

36: Short Form Health Survey. IPAQ-SF: International Physical Activity Questionnaire - Short Form. PPABS: Perceived Physical Activity Barriers Scale. *At time of study. 


\section{Quality appraisal results}

Quality appraisal of the final nine studies was completed utilising the Mixed Methods Appraisal Tool (Table 2). ${ }^{24}$ Based on the quality appraisal, three articles had a low risk of bias across all scoring domains. The remaining six articles scored 'unclear' or 'high' risk of bias across one or more domains. The quality appraisal highlighted an unclear risk of nonresponse bias in most studies. One study lacked complete data and the intervention was not administered as intended due to poor compliance of participants. ${ }^{14}$ Women with ovarian cancer were under represented in studies of mixed cancer cohorts. ${ }^{17,19,26-28}$ The studies that only investigated women with ovarian cancer contained small $(\mathrm{N}=<100)$ sample sizes. ${ }^{14,15}$ Studies that utilised questionnaires had pre-determined barriers and/or enablers, which may not capture the breadth or specificity of barriers/enablers experienced by cancer survivors. . $^{15,19,20}$ 
Table 2. Quality appraisal of studies assessed in the current rapid review. A score of 0 indicates a high risk of bias (dark grey), a score of 1 indicates an unclear risk of bias (medium grey) and a score of 2 indicates a low risk of bias (light grey).

\begin{tabular}{|c|c|c|c|c|c|c|c|}
\hline \multirow[t]{2}{*}{ Study type } & \multicolumn{7}{|c|}{ Item Number of Checklist } \\
\hline & 1 & 2 & 3 & 4 & 5 & 6 & 7 \\
\hline \multicolumn{8}{|c|}{ - $\quad$ Mixed Methods Studies ${ }^{a}$} \\
\hline Beck et al., 2020 & 2 & 2 & 2 & 2 & 2 & 2 & 2 \\
\hline Tyrrell et al., 2014 & 2 & 2 & 2 & 2 & 1 & 2 & 2 \\
\hline \multicolumn{8}{|c|}{$\begin{array}{l}\text { a Mixed Methods Item number check list key } \\
1 \text { - Are there clear research questions? } \\
2 \text { - Does the collected data answer the research questions? } \\
3 \text { - Is there an adequate rationale for using a mixed methods design to address the research question? } \\
4 \text { - Are the different components of the study effectively integrated to answer the research question? } \\
5 \text { - Are the outputs of the integration of qualitative and quantitative components adequately interpreted? } \\
6 \text { - Are divergences and inconsistencies between quantitative and qualitative results adequately addressed? } \\
7 \text { - Do the different components of the study adhere to the quality criteria of each tradition of the methods involved? }\end{array}$} \\
\hline \multicolumn{8}{|c|}{ - Quantitative Descriptive Studies ${ }^{b}$} \\
\hline Blaney et al., 2013 & 2 & 2 & 2 & 2 & 2 & 2 & 2 \\
\hline Farrokhzadi et al., 2016 & 2 & 2 & 2 & 2 & 2 & 1 & 2 \\
\hline Midtgaard et al., 2009 & 2 & 2 & 2 & 2 & 2 & 1 & 2 \\
\hline Mizrahi et al., 2015 & 2 & 2 & 2 & 2 & 2 & 1 & 2 \\
\hline \multicolumn{8}{|c|}{$\begin{array}{l}\text { b Item number check list key } \\
1 \text { - Are there clear research questions? } \\
2 \text { - Does the collected data answer the research questions? } \\
3 \text { - Is the sampling strategy relevant to address the research question? } \\
4 \text { - Is the sample representative of the target population? } \\
5 \text { - Are the measurements appropriate? } \\
6 \text { - Is the risk of nonresponse bias low? } \\
7 \text { - Is the statistical analysis appropriate to answer the research question? }\end{array}$} \\
\hline \multicolumn{8}{|c|}{ - Non-Randomised Studiesc } \\
\hline Zhang et al., 2017 & 2 & 1 & 2 & 2 & 0 & 1 & 0 \\
\hline \multicolumn{8}{|c|}{$\begin{array}{l}\text { 'Item number check list key } \\
1 \text { - Are there clear research questions? } \\
2 \text { - Does the collected data answer the research questions? } \\
3 \text { - Are the participants representative of the target population? } \\
4 \text { - Are measurements appropriate regarding the outcome and intervention? } \\
5 \text { - Are there complete outcome data? } \\
6 \text { - Are the confounders accounted for in the design and analysis? } \\
7 \text { - During the study period, is the intervention administered as intended? }\end{array}$} \\
\hline \multicolumn{8}{|c|}{ - $\quad$ Randomised Studies ${ }^{\mathrm{d}}$} \\
\hline Lapen et al., 2018 & 1 & 1 & 1 & 2 & 0 & 0 & 1 \\
\hline \multicolumn{8}{|c|}{$\begin{array}{l}\text { d Item number check list key } \\
1 \text { - Are there clear research questions? } \\
2 \text { - Does the collected data answer the research questions? } \\
3 \text { - Is randomisation appropriately performed? } \\
4 \text { - Are the groups comparable to baseline? } \\
5 \text { - Are there complete outcome data? } \\
6 \text { - Are outcome assessors blinded to the intervention provided? } \\
7 \text { - Did the participants adhere to the assigned intervention? }\end{array}$} \\
\hline \multicolumn{8}{|c|}{ - Qualitative Studiese } \\
\hline Midtgaard et al., 2012 & 2 & 2 & 2 & 2 & 2 & 2 & 2 \\
\hline $\begin{array}{l}\text { e Item number check list } k \\
1 \text { - Are there clear research } \\
2 \text { - Does the collected data } \\
3 \text { - Is the qualitative approa } \\
4 \text { - Are the qualitative data } \\
5 \text { - Are the findings adequa } \\
6 \text { - Is the interpretation of } t \\
7 \text { - Is there coherence betw }\end{array}$ & $\begin{array}{l}\text { estions? } \\
\text { wer the r } \\
\text { ippropria } \\
\text { ction me } \\
\text { derived f } \\
\text { esults su } \\
\text { qualitati }\end{array}$ & $\begin{array}{l}\text { dest } \\
\text { er th } \\
\text { quat } \\
\text { ta? } \\
\text { ubsta }\end{array}$ & $\begin{array}{l}\text { ques } \\
\text { s the }\end{array}$ & juest & & & \\
\hline
\end{tabular}




\section{Barriers to physical activity}

Barriers to participation in physical activity reported within each study are summarised in Table 3. Barriers were classified under the following four sub-categories.

(i) Treatment or disease related side effects: this category included any physical symptoms that occurred as a result of a cancer diagnosis and/or cancer treatment. These were the most common barriers across the reviewed literature. Fatigue and pain were the most prevalent, with six studies reviewed reporting these as barriers to physical activity. ${ }^{14,15,17-19,26}$ One study investigating physical activity in a sample of mixed cancer types reported $74 \%$ (N $=334$ ) of participants experienced fatigue as a barrier to participation. ${ }^{19}$ Among studies of ovarian cancer cohorts only, fatigue was reported as a barrier by $37.9 \%(\mathrm{~N}=36)$ of participants in one study. ${ }^{15}$ Diarrhoea and/or incontinence were reported in $22 \%$ of studies.

(ii) Personal attribute factors: barriers that shape behaviour were classified in this category. Fear of injury or falling and a lack of physical activity education were identified as barriers in $44 \%$ of studies of both mixed and ovarian cancer samples. ${ }^{15,17-19}$ Beyond these, lack of motivation or self-discipline, lack of routine, procrastination, exercise not a priority and lack of enjoyment or interest were other personal attribute factors. ${ }^{15,17-19}$

(iii) Environmental/social factors: environmental and social barriers were reported in $77 \%$ of studies. ${ }^{14,15,17-20,27}$ Time, lack of opportunity and lack of facilities/equipment were commonly reported barriers. Barriers less frequently identified were cost, significant life events and no support or company.

(iv) Program specific factors: only two program specific barriers were reported in the included literature. ${ }^{26,27}$ In one study of mixed cancer cohorts, researchers found the absence of tailored programs a barrier to adherence. ${ }^{26,27}$ Another study of breast and ovarian cancer survivors reported high exertion as a barrier to participation in physical activity. ${ }^{27}$ 


\section{Enablers to physical activity}

Enablers to participation in physical activity reported within each study are shown in Table 4. Enablers to physical activity were included in six studies. ${ }^{14,17,18,20,26,28}$ Enablers were classified under the following four sub-categories described below.

(i) Physical activity preferences: physical activity preferences included activity modality, time of day, location, intensity and delivery method. These were reported in $33 \%$ of studies. ${ }^{17,18,20}$ Physical activity preferences were similar amongst mixed and gynaecological cancer cohorts, with $71-95 \%$ of individuals preferring to walk, and 36-79\% preferring morning exercise. ${ }^{17,18,20}$ Moderate intensity physical activity was favoured by $60-84 \%$ of participants. ${ }^{17,20}$

(ii) Motivators: motivation to engage in physical activity was investigated in three studies. ${ }^{17,20,28}$ Improving quality of life, getting fit and gaining health benefits were the most common physical activity motivators.

(iii) Environmental/social factors: environmental or social enablers were captured in $55 \%$ of studies. In a study of mixed cancer survivors, $65.5 \%$ of participants $(\mathrm{N}=295)$ reported that approval from their treating oncologist to exercise would facilitate physical activity engagement. ${ }^{17}$ Support and education from health professionals was identified as a key enabler by both mixed cancer and ovarian cancer samples. ${ }^{14,18,20,26}$

(iv) Program specific factors: enablers specific to physical activity programs were found in $44 \%$ of studies. Individualised physical activity interventions with personal goals was the most common enabler to physical activity. ${ }^{17,28}$ More than $70 \%$ of participants in one study ${ }^{17}$ agreed or strongly agreed that factors such as enjoyment, a variety of exercises, gradual progression and good music were likely to facilitate exercise participation. 
Table 3. Barriers to physical activity participation reported across all studies including percentage (\%) of participants if reported in study.

\begin{tabular}{|c|c|c|c|c|c|c|c|c|c|}
\hline Author and Year & $\begin{array}{l}\text { Beck et al., } \\
2020\end{array}$ & $\begin{array}{l}\text { Blaney et al., } \\
2013\end{array}$ & $\begin{array}{l}\text { Farrokhzadi } \\
\text { et al., } 2016\end{array}$ & $\begin{array}{l}\text { Lapen et } \\
\text { al., } 2018\end{array}$ & $\begin{array}{l}\text { Midtgaard et al., } \\
2009\end{array}$ & $\begin{array}{l}\text { Midtgaard et } \\
\text { al., } 2012\end{array}$ & $\begin{array}{l}\text { Mizrahi et al., } \\
2015^{\star}\end{array}$ & $\begin{array}{l}\text { Tyrrell et } \\
\text { al., } 2014\end{array}$ & $\begin{array}{l}\text { Zhang et al., } \\
2017^{*}\end{array}$ \\
\hline \multicolumn{10}{|c|}{ (1) Treatment/Disease Related Side Effects } \\
\hline Pain & $\checkmark$ & $\checkmark$ & & & $\checkmark(45.0 \%)$ & & $\checkmark(20.0 \%)$ & & $\checkmark(70.0 \%)$ \\
\hline Fatigue & $\checkmark$ & $\checkmark$ & $\checkmark$ & & $\checkmark(74.0 \%)$ & & $\checkmark(37.9 \%)$ & & \\
\hline Diarrhoea/incontinence & $\checkmark$ & & $\checkmark$ & & & & & & \\
\hline \multicolumn{10}{|l|}{ (2) Personal Attribute Factors } \\
\hline Lack of motivation or self-discipline & & $\checkmark$ & & & & & $\checkmark(32.6 \%)$ & & \\
\hline Fear of injury or falling & & $\checkmark$ & $\checkmark$ & & $\checkmark(14.0 \%)$ & & $\checkmark(13.7 \%)$ & & \\
\hline Lacking education or never been active & & $\checkmark$ & $\checkmark$ & & $\checkmark$ & & $\checkmark(12.6 \%)$ & & \\
\hline Lack of routine & & & & & & & $\checkmark(34.7 \%)$ & & \\
\hline Procrastination & & & & & & & $\checkmark(27.4 \%)$ & & \\
\hline Not a priority & & & & & & & $\checkmark(24.2 \%)$ & & \\
\hline Lack of enjoyment or interest & & & $\checkmark$ & & & & $\checkmark(22.1-26.3 \%)$ & & \\
\hline \multicolumn{10}{|l|}{ (3) Environmental/Social Factors } \\
\hline Time/lack of opportunity & & & $\checkmark$ & $\checkmark$ & $\checkmark(14.0 \%)$ & & $\checkmark(15.8 \%)$ & & \\
\hline Weather extremes & & $\checkmark$ & & & & & $\checkmark(14.7 \%)$ & & $\checkmark$ \\
\hline Lack of facilities and/or equipment & & $\checkmark$ & $\checkmark$ & $\checkmark$ & & & $\checkmark(15.8 \%)$ & $\checkmark$ & \\
\hline Cost & & & & & & & $\checkmark(8.4 \%)$ & $\checkmark$ & \\
\hline Significant life events & & & & & & & & & $\checkmark(60.0 \%)$ \\
\hline No support or company & & & $\checkmark$ & & & & $\checkmark(21.1 \%)$ & & \\
\hline \multicolumn{10}{|l|}{ (4) Program Specific Factors } \\
\hline Program not specific enough/too general & $\checkmark$ & & & & & & & & \\
\hline High exertion & & & & $\checkmark$ & & & & & \\
\hline
\end{tabular}

*Studies with only ovarian cancer participants. 
Table 4. Enablers to physical activity participation reported across all studies, including percentage (\%) of participants if reported in study.

\begin{tabular}{|c|c|c|c|c|c|c|c|c|c|}
\hline Author and Year & Beck et al., 2020 & Blaney et al., 2013 & $\begin{array}{l}\text { Farrokhzadi } \\
\text { et al., } 2016\end{array}$ & $\begin{array}{l}\text { Lapen et } \\
\text { al., } 2018\end{array}$ & $\begin{array}{l}\text { Midtgaard et } \\
\text { al., } 2009\end{array}$ & $\begin{array}{l}\text { Midtgaard } \\
\text { et al., } 2012\end{array}$ & $\begin{array}{l}\text { Mizrahi et } \\
\text { al., 2015* }\end{array}$ & $\begin{array}{l}\text { Tyrrell et al., } \\
2014\end{array}$ & $\begin{array}{l}\text { Zhang et al., } \\
2017^{*}\end{array}$ \\
\hline \multicolumn{10}{|l|}{ (1) Physical Activity Preferences } \\
\hline Modality: walking & & $\checkmark(76.7 \%)$ & $\checkmark(71.0 \%)$ & & & & & $\checkmark(95.0 \%)$ & \\
\hline Moderate intensity physical activity & & $\checkmark(60.2 \%)$ & & & & & & $\checkmark(84.0 \%)$ & \\
\hline Time of day: morning & & $\checkmark(36.6 \%)$ & & & & & & $\checkmark(79.0 \%)$ & \\
\hline Exercise with friends and//or family & & & $\checkmark(37.0 \%)$ & & & & & $\checkmark(71.0-76.0 \%)$ & \\
\hline Exercise with other cancer survivors & & $\checkmark(40.0 \%)$ & & & & & & $\checkmark(48.0 \%)$ & \\
\hline \multicolumn{10}{|l|}{ (2) Motivators } \\
\hline Improve quality of life & & $\checkmark(64.5 \%)$ & & & & $\checkmark$ & & & \\
\hline Get fithealth benefits & & $\checkmark(60.4 \%)$ & & & & & & $\checkmark$ & \\
\hline Fatigue management & & $\checkmark(50.9 \%)$ & & & & & & & \\
\hline Fear of cancer recurrence & & & & & & $\checkmark$ & & & \\
\hline \multicolumn{10}{|l|}{ (3) Environmental/Social Factors } \\
\hline Approval from oncologist & & $\checkmark(65.7 \%)$ & & & & & & & \\
\hline Support and education from health professional & $\checkmark$ & & $\checkmark$ & & & & & $\checkmark$ & $\checkmark$ \\
\hline Feedback about progress & & $\checkmark(66.2 \%)$ & & & & & & & \\
\hline Activity registration (via diary or tracker) & $\checkmark$ & & & & & & & & $\checkmark$ \\
\hline \multicolumn{10}{|l|}{ (4) Program Specific Factors } \\
\hline Tailored intervention with personalised goals & $\checkmark$ & $\checkmark(73.1 \%)$ & & & & $\checkmark$ & & & \\
\hline Fun & & $\checkmark(88.0 \%)$ & & & & & & & \\
\hline Variety of exercises & & $\checkmark(81.8 \%)$ & & & & & & & \\
\hline Gradual progression & & $\checkmark(78.9 \%)$ & & & & & & & \\
\hline Flexible program & & $\checkmark(75.5 \%)$ & & & & & & $\checkmark(54 \%)$ & $\checkmark$ \\
\hline Good music & & $\checkmark(73.2 \%)$ & & & & & & & \\
\hline
\end{tabular}

${ }^{*}$ Studies with only ovarian cancer participants. 


\section{DISCUSSION}

This rapid review aimed to investigate the barriers and enablers to physical activity participation in women with ovarian cancer. While this topic has been investigated in other cancer cohorts, this is the first rapid review conducted in this clinical area. This rapid review found the most common barriers to physical activity were treatment or disease related side effects and environmental or social factors. ${ }^{15,17,18}$ The primary enablers identified were related to physical activity preferences (such as mode and timing of exercise) and environmental or social factors (e.g. guidance and support from medical/health professionals). ${ }^{14,17,18}$ This discussion presents the findings of mixed, female gynaecological and ovarian cancer survivors, and investigates the similarities and differences between each to inform future research directions. The implications of the study findings are discussed below.

Across the included study populations, mixed cancer survivor samples included a range of cancer types, such as breast, prostate, colon, haematological and ovarian cancer. Within samples of mixed cancer survivors, treatment and/or disease related side effects were highlighted as a common barrier to physical activity participation. ${ }^{17,19}$ The most disabling side effects reported to interfere with participation in physical activity were fatigue, pain and diarrhoea or incontinence. ${ }^{17,19,26}$ Cancer related fatigue is prevalent across all cancer types and can be highly burdensome, particularly if fatigue persists after the conclusion of treatment. ${ }^{29}$ There is strong evidence for the use of tailored physical activity interventions to combat cancer related fatigue..$^{9,12,29}$ Literature also recommends the inclusion of physical activity programs for cancer survivors to reduce faecal and urinary incontinence via pelvic floor exercises and resistance training. ${ }^{12}$ This evidence demonstrates the important role physical activity has in combatting such side effects. Personal attribute factors and environmental/social factors were commonly reported as barriers. These personal attribute and environmental/social barriers may be addressed by ensuring cancer survivors have access to low-cost exercise facilities and 
physical activity educational tools (such as cancer specific pamphlets). ${ }^{30}$

Female gynaecological cancer survivors encompass women with cervical, endometrial, ovarian, uterine and vaginal cancers. Two studies ${ }^{18,20}$ in this rapid review investigated the physical activity barriers, correlations and preferences in female gynaecological cancers. Findings in these studies were similar to mixed cancer survivors, with side effects such as fatigue and diarrhoea identified as physical activity barriers. ${ }^{18}$ Cancer related fatigue is a common symptom in women with gynaecological cancer and similar to mixed cancer survivors, evidence supports physical activity interventions to combat fatigue. ${ }^{17,31-33}$ Equivalent to mixed cancer survivors, gynaecological cancer survivors also reported lacking physical activity education and support. ${ }^{18}$ Educational programs for medical and allied health professionals could be implemented to ensure all staff working in oncology communicate consistent physical activity recommendations to cancer survivors. ${ }^{30}$

Semi-structured interviews conducted in a sample $(\mathrm{N}=16)$ of female gynaecological cancer survivors identified the importance of programs offered close to home, as travelling long distances during times of illness was reported to be unrealistic by the participants. ${ }^{20}$ The women in this study also highlighted cost as a barrier when required to take time off work during periods of treatment or illness resulting in a loss of income. ${ }^{20}$ In comparison, cost and travel concerns were not reported as a perceived barrier in mixed cancer cohorts. These findings suggest home programs during treatment may be more suitable in gynaecological cancer cohorts, ${ }^{20}$ whereby eliminating cost and travel requirements increases physical activity adherence. Home programs have been used effectively in other cancer cohorts, as a systematic review $(K=20)$ of breast cancer survivors showed home based walking programs successfully increased physical activity participation. ${ }^{34}$ A 26 -week home aerobic exercise intervention in a sample $(\mathrm{N}=10)$ of women with ovarian cancer also showed significant increases in physical activity, suggesting home based interventions are also suitable in this cohort. ${ }^{14}$ 
Women with ovarian cancer reported similar physical activity barriers to other cancer populations. Studies of ovarian cancer survivors found $20-70 \%$ of women perceived fatigue as a barrier to physical activity engagement. ${ }^{14,15}$ Survivors with Stage I (in which the cancer has not spread beyond the ovaries) ovarian cancer reported the least number of physical activity barriers and the highest participation in physical activity. ${ }^{15}$ This is unsurprising, given the higher treatment and disease burden associated with advanced stage ovarian cancer. ${ }^{35} \mathrm{~A}$ small proportion of women with ovarian cancer reported cost as a barrier, ${ }^{15}$ consistent with findings in gynaecological cancer survivors. ${ }^{20}$ Other barriers which were unique to ovarian cancer included lack of routine, procrastination and significant life events, ${ }^{14,15}$ although no further detail were reported as these findings were obtained from questionnaires. These findings highlight the paucity of research to date on this cancer survivor cohort.

Although enablers were not identified as frequently in the literature, this doesn't discount their importance, as they are key to facilitating participation in physical activity and providing solutions to barriers. ${ }^{36}$ Common enablers to physical activity participation fall under physical activity preferences, with studies in mixed and gynaecological cancer cohorts reporting that participants preferred walking and morning activity. ${ }^{17,18,20}$ The preference for walking programs may be linked to low cost and minimal travel requirements, which were cited as barriers in gynaecological and ovarian cancer cohorts. ${ }^{15,20}$ Other enablers reported in mixed cancer survivor cohorts were motivation to improve quality of life and physical fitness, reduce fatigue and gain overall health benefits. ${ }^{17,28}$ These motivations have been reported in other literature, which investigated long term physical activity maintenance in cancer survivors. $^{28}$

Approval from the participant's treating oncologist was reported to enable physical activity participation in a sample of mixed cancer survivors, ${ }^{17}$ which is supported by other evidence in women with breast and gynaecological cancer. ${ }^{30,37}$ Gynaecological and ovarian 
cancer survivors also highlighted the need for support and education from a health professional, underscoring the importance of a multi-disciplinary team approach to facilitate physical activity engagement. ${ }^{14,18}$ Medical and allied health professionals with cancer care training are well positioned to deliver physical activity interventions that are safe and evidence-based. ${ }^{12}$ Activity registration was reported as another motivator for women with ovarian cancer to initiate and adhere to a physical activity intervention. ${ }^{14}$ Activity registration has been investigated in breast cancer survivors, who reported increased motivation and accountability to exercise when using wearable activity trackers over a four week period. ${ }^{38}$ Future physical activity interventions designed for ovarian cancer survivors may consider the addition of activity registration to increase motivation and adherence in the initial stages of a physical activity intervention. Another theme consistent across all cancer samples was the need for physical activity programs to be individualised and allow for flexibility in its' delivery. ${ }^{14,17,19,28}$ This is unsurprising given the varied and time intensive treatment schedules cancer survivors are often subject to, ${ }^{4}$ in addition to other family and work responsibilities ${ }^{15}$. Physical activity programs designed for ovarian cancer survivors must be flexible and accommodate these responsibilities. Programs should also focus on reducing primary barriers to participation and utilise known enablers to promote engagement. Other recommendations will rely on future research conducted in women with ovarian cancer to investigate barriers and enablers to physical activity participation.

The literature included in this rapid review had several limitations. Many studies investigating barriers and enablers utilised outcome measures such as questionnaires which did not allow for open ended answers. ${ }^{15,18,20}$ In addition, many questionnaires rely on self-reported data, introducing possible recall bias. ${ }^{19}$ The evidence did not report on additional comorbidities or unique lifestyle factors that may influence physical activity participation, with researchers 
suggesting comorbidity data should be included in future research. ${ }^{17}$

\section{STRENGTHS AND LIMITATIONS}

The strength of this rapid review was the inclusion of both qualitative and quantitative literature. This rapid review followed a clear and transparent process to enable replication. The use of the Mixed Methods Appraisal Tool ${ }^{24}$ was also a strength, given its' ability to assess the methodological quality across a number of different study designs. The findings of this rapid review are confined to the methodological limitations across the included studies. Given that this was a rapid review with a limited timeframe, full text screening, data extraction and the quality appraisal were only completed by one reviewer. Despite this, the researcher discussed the progress of the review at each stage with her supervisory team at weekly supervision meetings. Another limitation of this review is the absence of research in the subject area, with only two ${ }^{14,15}$ studies included in this review investigating the perceptions of only women with ovarian cancer in regards to barriers and enablers to physical activity participation. The other studies included in the review had a mix of cancer diagnosis, including women with ovarian cancer, meaning findings are not specific to ovarian cancer.

\section{DIRECTIONS FOR FUTURE RESEARCH}

Given the developing evidence base in this clinical area it is difficult to make definitive conclusions regarding the perceived barriers and enablers to physical activity participation in women with ovarian cancer. Further research should utilise the strengths of qualitative and quantitative approaches to capture the unique challenges faced by women with ovarian cancer that both prevent and enable participation in physical activity. Noteworthy, very little qualitative research has been conducted to explore the experiences of women affected by ovarian cancer, specifically related to the barriers and enablers. Future qualitative research 
could capture women's unique experiences that questionnaire-based surveys are unable to clearly discern or completely overlook. ${ }^{15}$ Future research might also explore include a range of clinical, demographic and psycho-social factors (such as self-management self-efficacy, coping, anxiety and depression and social support) which impact on the experience of physical activity in women. Finally, an exploration of the unique side effects of treatment which pose the greatest difficulty to participating in physical activity would be important to understand.

\section{CONCLUSION}

Most women with ovarian cancer are sedentary, despite the range of benefits adopting a physical activity regime can offer. This rapid review found the primary barriers experienced by this population are linked to treatment or disease related side effects (primarily fatigue) and personal attribute factors such as lack of motivation or routine. This rapid review also identified that women with ovarian cancer require support and education from medical and health professionals who are well positioned to facilitate physical activity engagement. Further research in this area will help develop more targeted exercise guidelines assisting allied health, nursing and medical professionals to develop tailored interventions to increasing physical activity participation, which will have the potential to greatly improve quality of life in women with ovarian cancer.

\section{Funding source}

This research did not receive any specific grant from funding agencies in the public, commercial or not-for-profit sectors. 


\section{Acknowledgements}

The authors would like to thank Murray Turner from the University of Canberra library for his assistance in developing literature search strategies. 


\section{REFERENCES}

1. Australian Institute of Health and Welfare 2019. Cancer in Australia. www.aihw.gov.au/reports/cancer/cancer-in-australia-2019/; 2019 Accessed 12 Apr 2020.

2. Beesley VL, Price MA, Butow PN, Green AC, Olsen CM, Group AOCS, et al. Physical activity in women with ovarian cancer and its association with decreased distress and improved quality of life. J Psycho-Oncol. 2010;20(11):1161-9. DOI: 10.1002/pon.1834.

3. Roland KB, Rodriguez JL, Patterson JR, Trivers KF. A literature review of the social and psychological needs of ovarian cancer survivors. J Psycho-Oncol. 2013;22(11):2408-18. DOI: 10.1002/pon.3322.

4. Ushijima K. Treatment for recurrent ovarian cancer-at first relapse. J Oncol. 2010. DOI: $10.1155 / 2010 / 497429$.

5. Lin K-Y, Edbrooke L, Granger CL, Denehy L, Frawley HC. The impact of gynaecological cancer treatment on physical activity levels: a systematic review of observational studies. Brazil J Phys Therap. 2019;23(2):79-92. https://doi.org/10.1016/j.bjpt.2018.11.007.

6. Wenzel LB, Donnelly JP, Fowler JM, Habbal R, Taylor TH, Aziz N, et al. Resilience, reflection, and residual stress in ovarian cancer survivorship: A gynecologic oncology group study. J Psycho-Oncol. 2002;11(2):142-53. DOI: 10.1002/pon.567.

7. Caspersen CJ, Powell KE, Christenson GM. Physical activity, exercise, and physical fitness: definitions and distinctions for health-related research. Pub Health Rep. $1985 ; 100(2): 126-31$.

8. Reibe D, Ehrman JK, Ligouri G, Magal M. ACSM's Guidelines for Exercise Testing and Prescription. $10^{\text {th }}$ ed. Philadelphia; PA: Wolters Kluwer; 2018. 
9. Fuller JT, Hartland MC, Maloney LT, Davison K. Therapeutic effects of aerobic and resistance exercises for cancer survivors: a systematic review of meta-analyses of clinical trials. Br J Sports Med. 2018;52(20):1311. DOI: 10.1136/bjsports-2017098285.

10. Newton RU, Galvao DA. Exercise in prevention and management of cancer. Curr Treat Options Oncol. 2008;9(2-3):135-46. DOI: 10.1007/s11864-008-0065-1.

11. Cormie P, Atkinson M, Bucci L, Cust A, Eakin E, Hayes S, et al. Clinical Oncology Society of Australia position statement on exercise in cancer care. Med J Aus. 2018;209(4):184-7. https://doi.org/10.5694/mja18.00199.

12. Hayes SC, Newton RU, Spence RR, Galvão DA. The Exercise and Sports Science Australia position statement: Exercise medicine in cancer management. $J$ Sci Med Sport. 2019;22(11):1175-1199. https://doi.org/10.1016/j.jsams.2019.05.003.

13. Mizrahi D, Broderick C, Friedlander M, Ryan M, Harrison M, Pumpa K, et al. An exercise intervention during chemotherapy for women with recurrent ovarian cancer: a feasibility study. Int J Gynecol Cancer. 2015;25(6):985-92. http://dx.doi.org/10.1097/IGC.0000000000000460

14. Zhang X, McClean D, Ko E, Morgan MA, Schmitz K. Exercise Among Women With Ovarian Cancer: A Feasibility and Pre-/Post-Test Exploratory Pilot Study. Oncol Nurs Forum. 2017;44(3):366-74. DOI: 10.1188/17.ONF.366-374.

15. Mizrahi D, Broderick C, Samara J, Ryan M, Friedlander M. Physical activity in women with ovarian cancer: investigating the barriers and feasibility of exercise. Int $J$ Gynecol Cancer. 2015;25(4):577-583. DOI: 10.1097/IGC.0000000000000349.

16. Schmitz KH, Courneya KS, Matthews C, Demark-Wahnefried W, Galvão DA, Pinto BM, et al. American College of Sports Medicine roundtable on exercise guidelines for 
cancer survivors. J Med Sci Sports Ex. 2010;42(7):1409-26. DOI:

10.1249/MSS.0b013e3181e0c112.

17. Blaney J, Lowe-Strong A, Rankin-Watt J, Campbell A, Gracey J. Cancer survivors' exercise barriers, facilitators and preferences in the context of fatigue, quality of life and physical activity participation: a questionnaire-survey. J Psycho-Oncol. 2013;22(1):186-94. DOI: 10.1002/pon.2072.

18. Farrokhzadi L, Dhillon HM, Goumas C, Young JM, Cust AE. Physical activity correlates, barriers, and preferences for women with gynecological cancer. Int $J$ Gynecol Cancer. 2016;26(8):1530-7. DOI: 10.1097/IGC.0000000000790.

19. Midtgaard J, Baadsgaard MT, Moller T, Rasmussen B, Quist M, Andersen C, et al. Self-reported physical activity behaviour; exercise motivation and information among Danish adult cancer patients undergoing chemotherapy. Eur J Oncol Nurs. 2009;13(2):116-21. DOI: 10.1016/j.ejon.2009.01.006.

20. Tyrrell A, Keats M, Blanchard C. The physical activity preferences of gynecologic cancer survivors. Oncol Nurs Forum. 2014;41(5)461- 469. DOI: 10.1188/14.ONF.461-469.

21. Clifford BK, Mizrahi D, Sandler CX, Barry BK, Simar D, Wakefield CE, et al. Barriers and facilitators of exercise experienced by cancer survivors: a mixed methods systematic review. J Support Care Cancer. 2018;26(3):685-700. https://doi.org/10.1007/200520-017-3964-5.

22. Stevinson C, Capstick V, Schepansky A, Tonkin K, Vallance JK, Ladha AB, et al. Physical activity preferences of ovarian cancer survivors. J Psycho-Oncol. 2009;18(4):422-8. DOI: 10.1002/pon.1396. 
23. Garrity C, Gartlehner G, Kamel C, King VJ, Nussbaumer-Streit B, Stevens A, Hamel C, Affengruber L. Cochrane Rapid Reviews. Interim Guidance from the Cochrane Rapid Reviews Methods Group. March 2020.

24. Hong QN, Pluye P, Fàbregues S, Bartlett G, Boardman F, Cargo M, Dagenais P, Gagnon M-P, Griffiths F, Nicolau B, O’Cathain A, Rousseau M-C, Vedel I. Mixed Methods Appraisal Tool (MMAT), version 2018. Registration of Copyright (\#1148552), Canadian Intellectual Property Office, Industry Canada.

25. Whittemore R, Knafl K. The integrative review: updated methodology. J Adv Nurs. 2005;52(5):546-53. https://doi.org/10.1111/j.1365-2648.2005.03621.x.

26. Beck A, Vind Thaysen H, Hasselholt Soegaard C, Blaakaer J, Seibaek L. Prehabilitation in cancer care: patients' ability to prepare for major abdominal surgery. Scand J Caring Sci. 2020. DOI: 10.1111/scs.12828.

27. Lapen K, Benusis L, Pearson S, Search B, Coleton M, Li QS, et al. A Feasibility Study of Restorative Yoga Versus Vigorous Yoga Intervention for Sedentary Breast and Ovarian Cancer Survivors. Int J Yoga Therap. 2018;28(1):79-85. DOI: $10.11761 / 2018-00039$.

28. Midtgaard J, Røssell K, Christensen JF, Uth J, Adamsen L, Rørth M. Demonstration and manifestation of self-determination and illness resistance - a qualitative study of long-term maintenance of physical activity in posttreatment cancer survivors. $J$ Support Care Cancer. 2012;20(9):1999-2008. DOI: 10.1007/s00520-011-1304-8.

29. Mustian KM, Alfano CM, Heckler C, Kleckner AS, Kleckner IR, Leach CR, et al. Comparison of pharmaceutical, psychological, and exercise treatments for cancerrelated fatigue: a meta-analysis. JAMA Oncol. 2017;3(7):961-8. DOI: 10.1001/jamaoncol.2016.6914. 
30. Pennington KP, McTiernan A. The role of physical activity in breast and gynecologic cancer survivorship. J Gynecol Oncol. 2018;149(1):198-204.

https://doi.org/10.1016/j.ygyno.2018.01.020.

31. Arriba LN, Fader AN, Frasure HE, Von Gruenigen VE. A review of issues surrounding quality of life among women with ovarian cancer. J Gynecol Oncol. 2010;119(2):390-6.

32. Sekse RJT, Hufthammer KO, Vika ME. Fatigue and quality of life in women treated for various types of gynaecological cancers: a cross-sectional study. J Clinic Nurs. 2015;24(3-4):546-55. https://doi.org/10.1016/j.ygyno.2010.05.014.

33. Donnelly C, Blaney J, Lowe-Strong A, Rankin J, Campbell A, McCrum-Gardner E, et al. A randomised controlled trial testing the feasibility and efficacy of a physical activity behavioural change intervention in managing fatigue with gynaecological cancer survivors. J Gynaecol Oncol. 2011;122(3):618-24.

https://doi.org.10.1016/j.ygyno.2011.05.029.

34. Coughlin SS, Caplan L, Stone R, Stewart J. A review of home-based physical activity interventions for breast cancer survivors. Curr Cancer Rep. 2019;1(1):6. DOI: 10.25082/CCR.2019.01.002.

35. Coleman RL, Monk BJ, Sood AK, Herzog TJ. Latest research and treatment of advanced-stage epithelial ovarian cancer. Nature Reviews Clinic Oncol. 2013;10(4):211. DOI: 10.1038/nrcliniconc.2013.5

36. Blaney J, Lowe-Strong A, Rankin J, Campbell A, Allen J, Gracey J. The cancer rehabilitation journey: barriers to and facilitators of exercise among patients with cancer-related fatigue. Phys Therapy. 2010;90(8):1135-47. https://doi.org/10.2522/ptj.20090278. 
37. Jones LW, Courneya KS, Fairey AS, Mackey JR. Effects of an oncologist's recommendation to exercise on self-reported exercise behavior in newly diagnosed breast cancer survivors: a single-blind, randomized controlled trial. Ann Behav Med. 2004;28(2):105-13. https://doi.org/10.1207/s15324796abm2802_5.

38. Nguyen NH, Hadgraft NT, Moore MM, Rosenberg DE, Lynch C, Reeves MM, et al. A qualitative evaluation of breast cancer survivors' acceptance of and preferences for consumer wearable technology activity trackers. $J$ Support Care Cancer. 2017;25(11):3375-84. https://doi.org/10.1007/s00520-017-3756-y. 